\title{
A SCALABILITY STUDY USING SUPERCOMPUTERS FOR HUGE FINITE ELEMENT VARIABLY SATURATED FLOW SIMULATIONS*
}

\author{
FRED T. TRACY † THOMAS C. OPPE $\ddagger$ WILLIAM A. WARD§ AND MAUREEN K. CORCORAN
}

\begin{abstract}
This paper describes the challenges and scalability results of running a large finite element model of variably saturated flow in a three-dimensional (3-D) levee on a large high performance, parallel computer using a mesh with more than a billion nodes and two billion elements. MPI (Message Passing Interface) was used for the parallelization. The original finite element model consisted of 3,017,367 nodes and 5,836,072 3-D prism elements. The model exhibited three characteristics which made the problem difficult to solve. First, the different soil layers had soil properties that differed by several orders of magnitude. Secondly, there existed a $5 \mathrm{ft} \times 6 \mathrm{ft} \times 6 \mathrm{ft}$ region at the toe of the levee where the mesh was refined using 1 in $\times 1$ in $\times 1$ in 3 -D prism elements having randomly generated soil properties. Thirdly, variably saturated flow in levees is governed by the highly nonlinear Richards' equation.

A utility program was written to increase the size of the original problem by an arbitrarily large factor by replicating the original mesh in the $y$ direction. A factor of two, for instance, would exactly double the number of elements and double the number of nodes less the interface nodes connecting the two pieces. The original data set was run using 32, 64, 96, and 256 MPI processes (one core per process was used throughout this study) with time to solution taken for each of these process counts. The data set was then magnified by 2 and runs for $64,128,192$, and 512 processes were made with time to solution again recorded. This procedure was repeated for different numbers of processes and magnification values. The largest data set was generated from a magnification of 350 yielding a mesh of 1,044,246,303 nodes and 2,042,625,200 3-D prism elements. The Cray XE6 and Cray XC30 computers were used in this study. A tabulation of results is presented and analyzed, as well as the significant challenges that occurred in scaling up the problem size. Weak and strong scalability results are also presented in this paper.
\end{abstract}

Key words: high performance computing, finite element method, variably saturated seepage flow modeling

AMS subject classifications. 35J66, 65Y05, 76S05

1. Introduction. The maturing of large parallel supercomputers makes it possible to solve problems never before attempted. It is a trivial matter to ask for 100,000 or more cores in a batch submission script, but doing so without experimenting with gradually scaled-up problem sizes often leads to unexpected parallel inefficiencies, waste of resources, or even outright failure. This paper describes the challenges presented and the efforts made to run ever larger finite element groundwater models using up to a billion nodes and two billion 3-D prism elements. Weak and strong scaling were used to measure the success of the effort.

The problem chosen is a finite element simulation of variably saturated flow in porous media [1] where there are significant heterogeneities in the soil and difficult nonlinearities in the governing partial differential equation of Richards' equation [2]. Large systems of linear, simultaneous equations must also be solved hundreds of times using solvers such as the conjugate gradient method [3]. The matrices are often stored in a sparse matrix format leading to matrix-vector operations that involve irregular data patterns and indirect addressing. Clearly, the chosen problem is a difficult real-world problem to tackle.

2. Description of the problem. The problem consists of steady-state flow through a levee as shown in Fig. 2.1 and idealized in Fig. 2.2 where there are several soil layers with soil properties differing by 5 to 6 orders of magnitude (e.g., from clay with a low hydraulic conductivity to sand with a high hydraulic conductivity). Fig. 2.3 shows a portion of the 3 -D mesh of the levee system before a tree with its root system was added at the toe. More details are given in [4]. To model the tree root at the toe of the levee, a $5 \mathrm{ft} \times 6 \mathrm{ft} \times 6$ $\mathrm{ft}$ heterogeneous zone was added (see Fig. 2.4) in which the mesh was refined using 1 in $\times 1$ in $\times 1$ in 3 -D prism elements. To simulate heterogeneities, a randomly generated hydraulic conductivity was assigned to each element in this zone. The resulting mesh consisted of 3,017,367 nodes and 5,836,072 3-D prism elements.

${ }^{*}$ This work was supported in part by a grant of computer time from the Department of Defense High Performance Computing Modernization Program (HPCMP).

${ }^{\dagger}$ Information Technology Laboratory (ITL), Engineering Research and Development Center (ERDC), Vicksburg, MS, USA.

${ }^{\ddagger}$ ITL, ERDC, Vicksburg, MS, USA.

§ HPCMP, ITL, ERDC, Vicksburg, MS, USA.

『Geotechnical and Structures Laboratory, ERDC, Vicksburg, MS, USA. 


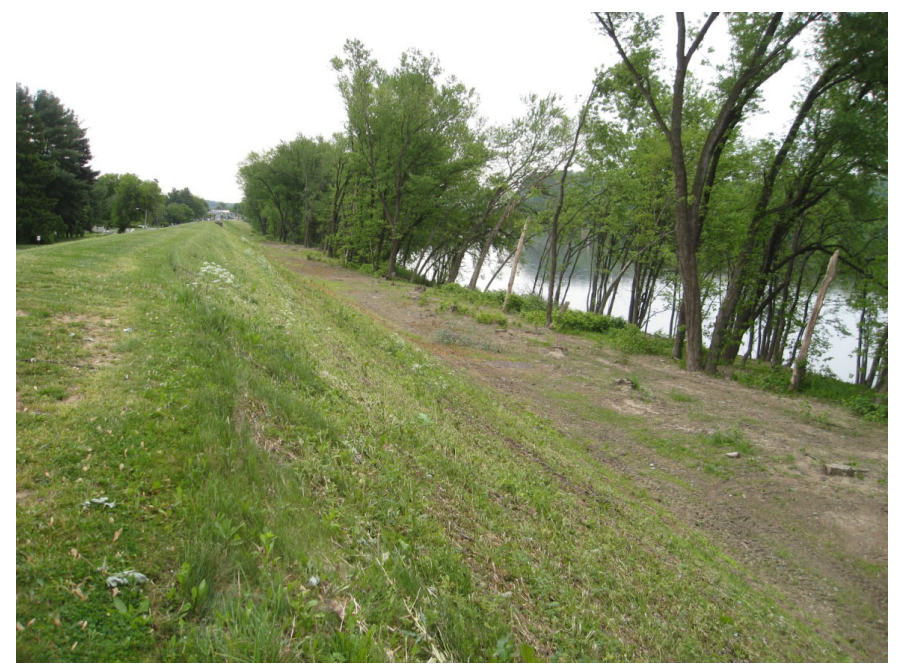

FIG. 2.1. River side of a levee with trees.

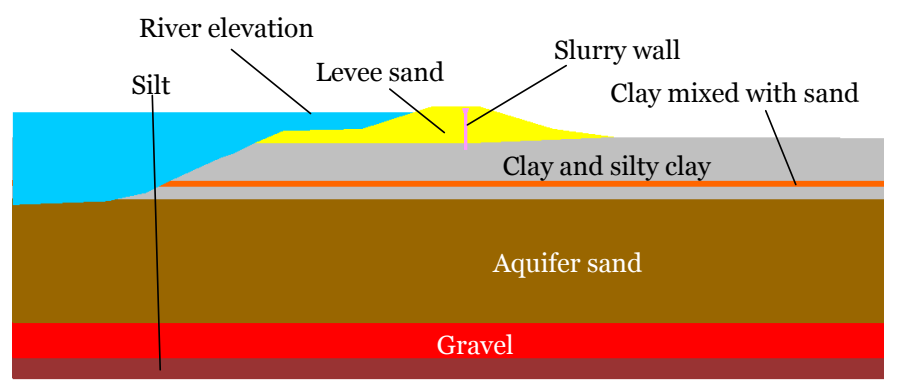

FIG. 2.2. Cross section of a levee with material types and elevation of the river.

3. Computational challenges. The many computational challenges inherent in this application were as follows:

- Complicated geometry. The geometry of the levee system contained several regions having different soil properties.

- Wide-ranging material property values. The soils in the levee ranged from sand to silt to clay, and the associated material properties such as hydraulic conductivity spanned several orders of magnitude [5].

- Nonlinear system of equations to solve. The system of equations resulting from the finite element discretization of the levee seepage flow problem was nonlinear because the flow was partially saturated and partially unsaturated. This required the repeated solution of a simultaneous, linear system of equations resulting from either a Picard or Newton linearization in conjunction with line search algorithms [6], [7], and [8]. As the number of nodes and elements increased, this computation became increasingly difficult.

- Ill-conditioned system of linear equations. When the soil is partially saturated, material properties such as relative hydraulic conductivity and moisture content become several orders of magnitude smaller as the soil becomes less and less moist. This adds additional stress to solving the linear system of equations at each nonlinear step. A study of preconditioners and solvers for the variably saturated problem is given in [9].

- Sparse matrix format. The coefficients of the matrices used in solving the linear system of equations at each nonlinear iteration were stored in sparse matrix format with indirect addressing. This irregular pattern of data decreased the efficiency of the computer for such things as vectorization of the matrixvector calculations. 




Fig. 2.3. Portion of the 3-D mesh before the root zone was added.

4. High performance parallel computing. A 3-D seepage/ground-water finite element program was parallelized using MPI [10] on Garnet, the Cray XE6 at ERDC [11], and on Lightning, the Cray XC30 at the Air Force Research Laboratory, Aberdeen, MD, USA [12]. Garnet consists of 4,716 dual-socket compute nodes with each socket populated with a $2.5 \mathrm{GHz}$ 16-core AMD 6200 Opteron (Interlagos) processor. Each node has 64 GB memory (60 GB user-accessible) or an average of $1.875 \mathrm{~GB}$ memory per core. The interconnect type is Cray Gemini in a 3-D torus topology. Garnet is rated at 1.5 peak PFLOPS or 10 GFLOPS per core. Garnet has a large Lustre file system that is tuned for parallel I/O. Lightning consists of 2,360 dual-socket compute nodes with each socket populated with a $2.7 \mathrm{GHz}$ 12-core Intel Xeon E5-2697v2 (Ivy Bridge) processor. Each node has 64 GB memory (63 GB user-accessible) or an average of 2.625 GB memory per core. The interconnect type is Cray Aries in a Dragonfly topology. Lightning is rated at 1.2 peak PFLOPS or 21.6 GFLOPS per core. Lightning has a large Lustre file system that is tuned for parallel I/O.

The parallelization of the 3-D seepage/groundwater program was broken into four separate parts, and each part was a stand-alone FORTRAN or C computer program. One MPI process was placed on each core of a compute node. The four programs will now be described.

- Partitioner. The mesh is partitioned using the Parallel Graph Partitioning and Fill-reducing Matrix Ordering program, ParMETIS [13], to divide the mesh into approximately equal pieces among the processes. This is illustrated in Fig. 4.1 where three parallel processes have the nodes of the mesh divided among them. The output of the first version of ParMETIS used was a single file containing a line for each finite element node stating to which process the given node belongs. As the problem size grew, the version of ParMETIS that distributes the output file over the processes in a block partition style was used. As seen in Fig. 4.1, some elements contained nodes belonging to different processes. Each element is assigned to that process that owns the first node of the element. Nodes of an element belonging to a particular process that are not owned by that process are called ghost nodes. Also some elements have nodes belonging to a particular process but that element does not belong to that process. These are called ghost elements, and they create even more ghost nodes.

- Preparer. The next piece of the solution creates a file for each process that contains the owned and ghost nodes and elements for that process using local numbers (see Sect. 5.2.2), a subset of the boundary condition file and initial condition file belonging to that process, a list of nodes where data are to be sent to every other process, a list of nodes where data are to be received from every other process, and 


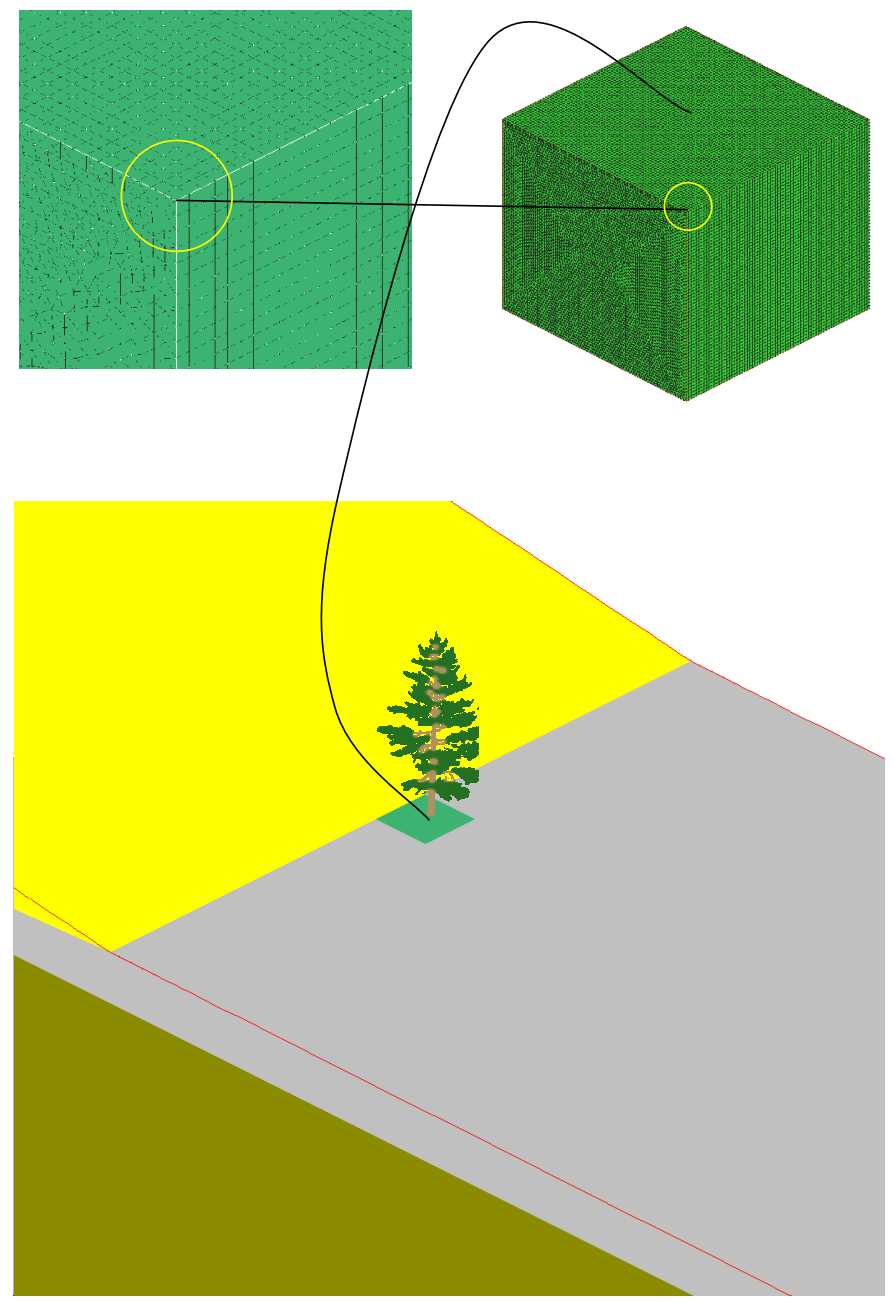

FIG. 2.4. Heterogeneous zone representing the roots of a tree.

global node and element numbers for the owned and ghost nodes and elements on that process.

- Finite element program. This part does the finite element computations with resulting output files containing results for each owned node of that process. This is the primary focus of the time-to-solution results presented later in this paper.

- Postprocessor. This final part is a postprocessor program that combines all data from each process into the final output files.

\section{Challenges.}

5.1. Partitioner. This original version of this program (written in C) simply reads in the geometry data file and calls one of the ParMETIS programs to produce a single file with a line of data for each node that gives the process that owns the node. That technique was adequate for the original problem with 3,017,367 nodes and smaller versions of the bigger meshes. For example, when the original data set is doubled $(m=2)$, the mesh has 6,000,831 nodes, and the partitioner program took only 6.3 seconds to run. At this size of problem, it was possible to use global arrays to store the mesh. However, as the problem size grew, the geometry files also continued to grow, and the time for reading this file into the program continued to grow as well.

5.1.1. No global arrays. The finite element mesh data needed for the partitioner took 710 Mbytes of memory for the original problem. However, magnifying the problem to $m=100$, for instance, required 68 


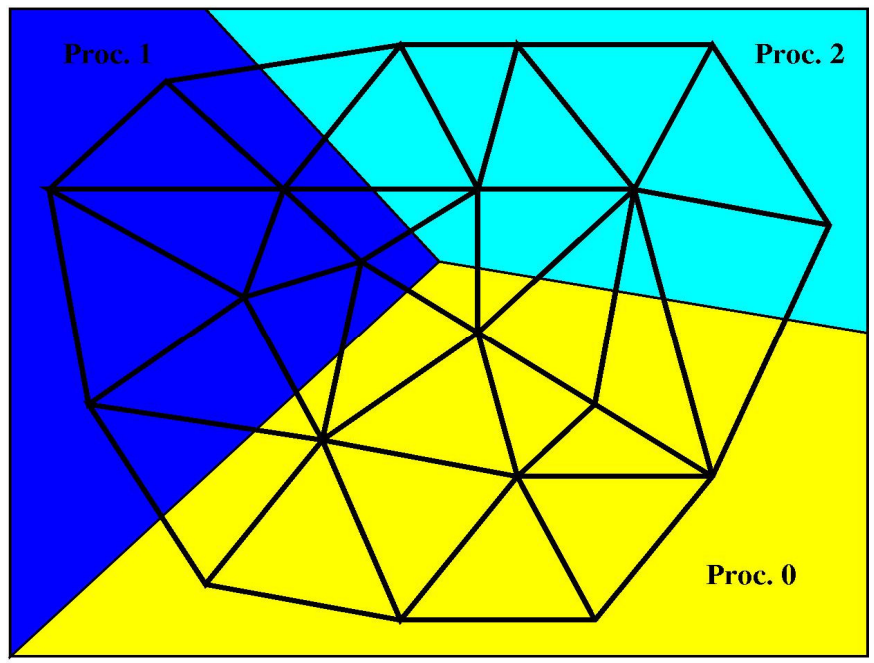

FIG. 4.1. An example of dividing a finite element mesh into several partitions.

Gbytes of memory to store this same data. This clearly illustrated why no global arrays can be allowed in any part of this application. To completely avoid this use of global arrays makes the process of parallelization much more difficult. It was decided to first read the mesh data and store it in the block partition format. Then the adjacency table routine [14] had to be modified to use this partitioned data. Finally, a different version of ParMETIS was called and the output file written to all the processes in block partition format.

5.1.2. No ASCII data file containing the entire mesh. The original version of this application had as one of its ASCII input files a file containing the nodes and elements. A node line began with the characters, GN, and an element line began with GE. Further, these type lines could be mixed in any order, requiring the reading and processing of one line at a time. As the problem size grew, the time to process the large geometry data files became prohibitive. For example, at $m=2$, the entire partitioner took 6.3 sec on Garnet and for $m=4$, the time was $11.8 \mathrm{sec}$ on Garnet. However, at $m=100$, the time to read this input file exceeded two hours.

Different solutions were suggested including rewriting the ASCII file as a binary fire. A better solution was to modify the serial program that generated the geometry file in the first place. Instead of writing one huge file, the new version of the serial program wrote node and element data for each process. Further, one file for nodes and one file for elements were written in a simpler format. In this new way, to create the data files for each process for $m=100$ took $2544.6 \mathrm{sec}$ on Garnet. However, since 3,200 processes were used for the seepage/groundwater program run, this is still less than one second per process. In the case of $m=100$ in which the grid data could not be read into the partitioner program in two hours using the previous approach, the new approach required only 1.9 seconds on Garnet for the same task.

5.2. Preparation program. When this research project began, it was thought that the parallelization of the actual finite element program would present the greatest challenge. However, because of the restriction of no global arrays, the preparation program was by far the most troublesome and could be improved further from the modifications that were made. Given below is a summary of the challenges faced for the preparation program.

5.2.1. No ASCII data file containing the entire mesh. The same problem existed with the preparation program as with the partitioner in that the time reading the very large geometry file became overwhelming. The same technique of reading the individual node and element files for each process worked well here, too.

5.2.2. Global, local, and ghost nodes and elements. Each node has an original global node number assigned to it, and it is the same everywhere. When the nodes are first and temporarily distributed evenly in 
the block partition style to the different processes, each node then has a local node number stating where it is placed on its process. Now ParMETIS dictates that a given node actually belongs to a different process than, in general, it now resides, giving rise to a second local node number. Also, elements are done exactly like the nodes; read in block partition format and then moved to their proper final process. As with the nodes, each element has two different local node numbers. As can be seen, managing all this data is very tedious.

5.2.3. Output files. The finite element program needs various files such that there is one for each process and all data use the final local node and element numbers. These files will now be briefly described.

- Mesh file. The list of local (owned plus ghost) nodes and elements are placed in this file. Before writing, the ghost nodes are sorted by increasing process number where the given node resides. For example, suppose for a small problem, process 0 has 10 owned nodes and 2 ghost nodes from process 1,3 ghost nodes from process 4 , and 1 ghost node from process 14 . The ghost node numbers are assigned local node numbers 11 and 12 for the process 1 ghost nodes, 13, 14, and 15 for the process 4 ghost nodes, and 16 for the process 14 ghost node. Getting all these data properly numbered and sorted without any arrays containing the entire mesh is remarkably challenging.

- Initial condition file. The original initial condition file contains a value of total head for each node to give the finite element program a place to start for iterating to a solution. A value for all the local nodes and elements is now needed for each process.

- Boundary condition file. The original file contains parameter data that is simply reproduced for the file for each process. However, boundary conditions are also applied to individual nodes with one example being the total head resulting from the elevation of a river. The original data has for this type of boundary condition the global node number and the total head associated with it. An initial way of handling such a boundary condition was to send the global node number to all the processes and then have each process search through the global node numbers associated with each local node to see if the node is on that process. If the node is on that process, that boundary condition line is written to that process' boundary condition file with the global node number being replaced with its local node number. As the problem size increased, so did the number of such boundary condition nodes to consider. This simple search had to be replaced with a hash formulation [15]. For $m=100$, the search time using the hash table was $7.5 \mathrm{sec}$ on Garnet.

- Combination of global node numbers, global element numbers, and ghost node data. A file for each process containing (1) the global node number for each local node, (2) the global element number for each local element, (3) the number of values and starting memory location for data received from the other processes, and (4) the number and values of the local node numbers where data are to be sent to all the other processes.

5.3. Finite element program. This is the major piece of the seepage/ground-water suite of programs that was tested and timed as it is the primary computational engine. It was initially thought that this would cause the greatest difficulty in running huge problems with large numbers of processes. However, there was only one place where global arrays were being used, so only this algorithm had to be revised. This was the ghost node update portion of the conjugate gradient solver where the data created by the preparer program was stored more efficiently.

\section{Results and Analysis.}

6.1. Results. Tables 6.1-6.12 give the time to solution for the finite element program on the Cray XE6 and XC30 for different problem sizes ( $m$ values) and process counts. The PGI [16] compiler with the compiler option "-fastsse" was used in the computer runs. The original problem was run with 32 MPI processes. The "weak" scaling or speedup in the tables refers to increasing the number of MPI processes the same amount as the problem size is increased. Thus, in Table $6.2, \frac{T_{m=1, p=32}}{T_{m=2, p=64}}$ means divide the time obtained from running the $m=1$ problem with 32 MPI processes by the time it took to run the $m=2$ problem with 64 MPI processes. As another example, when $m=100$, the number of processes used was 3200 for the weak scaling. The ideal result of the weak scaling ratios is always 1 .

"Strong" scaling in the paper refers to keeping the problem size the same while increasing the number of MPI processes and computing the ratio of the original and new running times. For example, $\frac{T_{m=1, p=32}}{T_{m=1, p=256}}$ in Table 
TABLE 6.1

Time (sec) for the Cray XE6 and XC30 for $m=1$, nodes $=3017367$, and elements $=5836072$.

\begin{tabular}{|c|c|c|c|c|c|c|}
\hline Processes $(p)$ & Cray & Time (T) & Strong Scaling & Ideal & Weak Scaling & Ideal \\
\hline 32 & $\begin{array}{c}\mathrm{XE6} \\
\mathrm{XC} 30\end{array}$ & $\begin{array}{c}2195.9 \\
902.1\end{array}$ & & & & \\
\hline.. & $\begin{array}{c}\text { XE6 } \\
\text { XC30 }\end{array}$ & $\begin{array}{c}2195.8 \\
899.6\end{array}$ & & & & \\
\hline .. & $\begin{array}{c}\mathrm{XE} 6 \\
\mathrm{XC} 30\end{array}$ & $\begin{array}{c}2199.7 \\
905.8\end{array}$ & & & & \\
\hline.. & $\begin{array}{c}\text { XE6 } \\
\text { XC30 } \\
\end{array}$ & $\begin{array}{l}\text { Avg: } 2197.1 \\
\text { Avg: } 902.7\end{array}$ & & & NA & NA \\
\hline 64 & $\begin{array}{c}\text { XE6 } \\
\text { XC30 }\end{array}$ & $\begin{array}{c}1082.7 \\
458.0\end{array}$ & & & & \\
\hline & $\begin{array}{c}\mathrm{XE} 6 \\
\mathrm{XC} 30\end{array}$ & $\begin{array}{c}1083.9 \\
461.3\end{array}$ & & & & \\
\hline. & $\begin{array}{c}\mathrm{XE6} 6 \\
\mathrm{XC} 30 \\
\end{array}$ & $\begin{array}{c}1079.1 \\
458.7 \\
\end{array}$ & & & & \\
\hline .. & $\begin{array}{c}\mathrm{XE6} \\
\mathrm{XC} 30\end{array}$ & $\begin{array}{l}\text { Avg: } 1081.9 \\
\text { Avg: } 459.3\end{array}$ & $\begin{aligned} & =2.03 \\
\frac{T_{m=1, p=32}}{T_{m=1, p=64}} & =1.97\end{aligned}$ & 2 & & \\
\hline 96 & $\begin{array}{c}\text { XE6 } \\
\text { XC30 }\end{array}$ & $\begin{array}{l}742.9 \\
320.5\end{array}$ & & & & \\
\hline & $\begin{array}{c}\mathrm{XE6} \\
\mathrm{XC} 30\end{array}$ & $\begin{array}{l}739.1 \\
318.9 \\
\end{array}$ & & & & \\
\hline & $\begin{array}{c}\mathrm{XE6} 6 \\
\mathrm{XC} 30 \\
\end{array}$ & $\begin{array}{l}737.2 \\
313.7 \\
\end{array}$ & & & & \\
\hline . & $\begin{array}{c}\text { XE6 } \\
\text { XC30 }\end{array}$ & $\begin{array}{l}\text { Avg: } 739.7 \\
\text { Avg: } 317.7\end{array}$ & $\begin{aligned} & =2.98 \\
\frac{T_{m=1, p=32}}{T_{m=1, p=96}} & =2.84\end{aligned}$ & 3 & & \\
\hline 256 & $\begin{array}{c}\mathrm{XE6} \\
\mathrm{XC} 30\end{array}$ & $\begin{array}{l}353.1 \\
128.9\end{array}$ & & & & \\
\hline.. & $\begin{array}{c}\mathrm{XE6} \\
\mathrm{XC} 30 \\
\end{array}$ & $\begin{array}{l}332.1 \\
122.8\end{array}$ & & & & \\
\hline .. & $\begin{array}{c}\mathrm{XE6} \\
\mathrm{XC} 30\end{array}$ & $\begin{array}{l}330.1 \\
127.9 \\
\end{array}$ & & & & \\
\hline$\cdot \cdot$ & $\begin{array}{c}\mathrm{XE} 6 \\
\mathrm{XC} 30 \\
\end{array}$ & $\begin{array}{l}\text { Avg: } 338.4 \\
\text { Avg: } 126.5 \\
\end{array}$ & $\begin{aligned} & =6.49 \\
\frac{T_{m=1, p=32}}{T_{m=1, p=256}} & =7.14\end{aligned}$ & 8 & & \\
\hline
\end{tabular}

6.1 refers to dividing the time it took to run the problem when $m=1$ using 32 MPI processes by the time it took to run the same problem with 256 MPI processes. The ideal scaling or speedup value is always the ratio of the new number of MPI processes and the original number of MPI processes. In the above example, the ideal speedup is 8 .

To test strong scaling, the process count was made 2,3 , and sometimes 8 times that of the original process count for given values of $m$. Values of $m=2,3,4,5,10,20,30,100,200,300$, and 350 were evaluated. The largest data set where $m=350$ contains 1,044,246,303 nodes and 2,042,625,200 elements.

Fig. 6.1 shows the results of the weak scaling. It is important to note that between $m=1$ and $m=2$, the number of elements exactly doubles, but the number of nodes less than doubles (slightly) due to interface nodes. Thus the amount of computation per process may be slightly less in the $m=2$ case for double the number of processes. Thus, weak scaling ratios may be slightly higher than they would be if a perfect doubling of the nodes was also done. Nevertheless, the ideal weak scaling is approximately 1. Figs. 6.2, 6.3, and 6.4 show plots of the strong scaling results. Table 6.13 shows a ratio of the running times for the XE6 and XC30 for different values of $m$. For multiple runs on the same machine using the same value of $m$, the elapsed times were averaged.

6.1.1. Analysis. The weak scaling was excellent throughout all the problem sizes and both computers with the XC30 results being better at the larger problem sizes. The strong speedup results were good on the XE6 until $m=200$ and the process count was increased 3 times such that the process count was 19,200. Also, the XE6 did poorly at $m=300$ when the process count was doubled. The XC30 consistently outperformed the 
TABLE 6.2

Time (sec) for the Cray XE6 and XC30 for $m=2$, nodes $=6000831$, and elements $=11672144$.

\begin{tabular}{|c|c|c|c|c|c|c|}
\hline Processes $(\mathrm{p})$ & Cray & Time $(\mathrm{T})$ & Strong Scaling & Ideal & Weak Scaling & Ideal \\
\hline 64 & $\begin{array}{c}\mathrm{XE} 6 \\
\mathrm{XC} 30\end{array}$ & $\begin{array}{l}2259.2 \\
897.9\end{array}$ & & & & \\
\hline .. & $\begin{array}{c}\text { XE6 } \\
\text { XC30 }\end{array}$ & $\begin{array}{c}2196.8 \\
908.3\end{array}$ & & & & \\
\hline .. & $\begin{array}{c}\text { XE6 } \\
\text { XC30 }\end{array}$ & $\begin{array}{c}2202.5 \\
904.1\end{array}$ & & & & \\
\hline .. & $\begin{array}{c}\mathrm{XE} 6 \\
\mathrm{XC} 30 \\
\end{array}$ & $\begin{array}{l}\text { Avg: } 2219.5 \\
\text { Avg: } 901.8 \\
\end{array}$ & & & $\begin{aligned} & =0.99 \\
\frac{T_{m=1, p=32}}{T_{m=2, p=64}} & =1.00\end{aligned}$ & 1 \\
\hline 128 & $\begin{array}{c}\mathrm{XE} 6 \\
\mathrm{XC} 30\end{array}$ & $\begin{array}{c}1097.4 \\
468.4\end{array}$ & & & & \\
\hline. & $\begin{array}{c}\text { XE6 } \\
\text { XC30 }\end{array}$ & $\begin{array}{c}1093.5 \\
460.5\end{array}$ & & & & \\
\hline .. & $\begin{array}{c}\text { XE6 } \\
\text { XC30 }\end{array}$ & $\begin{array}{c}1103.1 \\
460.1\end{array}$ & & & & \\
\hline .. & $\begin{array}{c}\text { XE6 } \\
\text { XC30 }\end{array}$ & $\begin{array}{l}\text { Avg: } 1098.0 \\
\text { Avg: } 463.0\end{array}$ & $\begin{aligned} & =2.02 \\
\frac{T_{m=2, p=64}}{T_{m=2, p=128}} & =1.95\end{aligned}$ & 2 & & \\
\hline 192 & $\begin{array}{c}\text { XE6 } \\
\text { XC30 }\end{array}$ & $\begin{array}{l}743.1 \\
312.9\end{array}$ & & & & \\
\hline .. & $\begin{array}{c}\mathrm{XE} 6 \\
\mathrm{XC} 30\end{array}$ & $\begin{array}{l}748.5 \\
316.4 \\
\end{array}$ & & & & \\
\hline .. & $\begin{array}{c}\mathrm{XE} 6 \\
\mathrm{XC} 30\end{array}$ & $\begin{array}{l}756.2 \\
314.7\end{array}$ & & & & \\
\hline .. & $\begin{array}{c}\mathrm{XE} 6 \\
\mathrm{XC} 30\end{array}$ & $\begin{array}{l}\text { Avg: } 749.3 \\
\text { Avg: } 314.7\end{array}$ & $\begin{aligned} & =2.96 \\
\frac{T_{m=2, p=64}}{T_{m=2, p=192}} & =2.85\end{aligned}$ & 3 & & \\
\hline 512 & $\begin{array}{c}\text { XE6 } \\
\text { XC30 }\end{array}$ & $\begin{array}{l}360.8 \\
130.4\end{array}$ & & & & \\
\hline .. & $\begin{array}{c}\mathrm{XE} 6 \\
\mathrm{XC} 30\end{array}$ & $\begin{array}{l}348.5 \\
130.2 \\
\end{array}$ & & & & \\
\hline .. & $\begin{array}{c}\mathrm{XE} 6 \\
\mathrm{XC} 30 \\
\end{array}$ & $\begin{array}{l}349.7 \\
130.5 \\
\end{array}$ & & & & \\
\hline .. & $\begin{array}{c}\mathrm{XE} 6 \\
\mathrm{XC} 30\end{array}$ & $\begin{array}{l}\text { Avg: } 353.0 \\
\text { Avg: } 133.7\end{array}$ & $\begin{aligned} & =6.29 \\
\frac{T_{m=2, p=64}}{T_{m=2, p=512}} & =6.72\end{aligned}$ & 8 & & \\
\hline
\end{tabular}

XE6 by a factor of approximately 2.5 .

7. Consistency check. A system of simultaneous, linear equations is solved each time one of 300 nonlinear iterations is done with the number of unknowns equal to the number of node points. Some parallel programs struggle with getting the same answers when the number of processes is increased. This test is much more difficult in that the size of the problem and the number of processes are increased as $m$ is increased. Table 7.1 gives pressure head results for the first few nodes and the last few nodes of the respective meshes for $m=1$ and $m=350$. Because of symmetry, these results should match. These numbers, in fact, match very well.

8. Conclusions. The following conclusions are made from this study:

- It is remarkable that even at over a billion nodes and two billion 3-D elements, the Cray XE6 and Cray XC30 can still be productively used as indicated by the speedup computations when comparing the times to solution of the original problem with data sets up to 350 times larger.

- The weak speedup values were excellent and about the same on both computers.

- The strong speedup capability began to fail for the XE6 at higher values of $m$. The XC30 values remained good for all problems that were run.

- The XC30 performed approximately 2.5 times better than the XE6.

- It is well known that reading ASCII files can be inefficient. For very large data sets, the problem becomes acute.

- For large problems, the use of global arrays in the source code becomes infeasible. 
TABLE 6.3

Time (sec) for the Cray XE6 and XC30 for $m=3$, nodes $=8984295$, and elements $=17508216$.

\begin{tabular}{|c|c|c|c|c|c|c|}
\hline Processes $(\mathrm{p})$ & Cray & Time (T) & Strong Scaling & Ideal & Weak Scaling & Ideal \\
\hline 96 & $\begin{array}{c}\text { XE6 } \\
\text { XC30 }\end{array}$ & $\begin{array}{c}2215.1 \\
906.1\end{array}$ & & & & \\
\hline .. & $\begin{array}{c}\text { XE6 } \\
\text { XC30 }\end{array}$ & $\begin{array}{c}2200.4 \\
898.0\end{array}$ & & & & \\
\hline .. & $\begin{array}{c}\text { XE6 } \\
\text { XC30 }\end{array}$ & $\begin{array}{c}2195.3 \\
901.8\end{array}$ & & & & \\
\hline .. & $\begin{array}{c}\text { XE6 } \\
\text { XC30 }\end{array}$ & $\begin{array}{l}\text { Avg: } 2203.6 \\
\text { Avg: } 902.0\end{array}$ & & & $\begin{aligned} & =1.00 \\
\frac{T_{m=1, p=32}}{T_{m=3, p=96}} & =1.00\end{aligned}$ & 1 \\
\hline 192 & $\begin{array}{c}\text { XE6 } \\
\text { XC30 }\end{array}$ & $\begin{array}{c}1097.3 \\
462.0\end{array}$ & & & & \\
\hline.. & $\begin{array}{c}\text { XE6 } \\
\text { XC30 } \\
\end{array}$ & $\begin{array}{l}1126.4 \\
462.6\end{array}$ & & & & \\
\hline .. & $\begin{array}{c}\text { XE6 } \\
\text { XC30 }\end{array}$ & $\begin{array}{c}1117.2 \\
460.6\end{array}$ & & & & \\
\hline .. & $\begin{array}{c}\text { XE6 } \\
\text { XC30 }\end{array}$ & $\begin{array}{l}\text { Avg: } 1113.6 \\
\text { Avg: } 461.7\end{array}$ & $\begin{aligned} & =1.98 \\
\frac{T_{m=3, p=96}}{T m=3, p=192} & =1.95\end{aligned}$ & 2 & & \\
\hline 288 & $\begin{array}{c}\text { XE6 } \\
\text { XC30 }\end{array}$ & $\begin{array}{l}751.0 \\
312.6\end{array}$ & & & & \\
\hline .. & $\begin{array}{c}\text { XE6 } \\
\text { XC30 }\end{array}$ & $\begin{array}{l}747.4 \\
313.7\end{array}$ & & & & \\
\hline .. & $\begin{array}{c}\text { XE6 } \\
\text { XC30 }\end{array}$ & $\begin{array}{l}750.2 \\
314.8\end{array}$ & & & & \\
\hline .. & $\begin{array}{c}\text { XE6 } \\
\text { XC30 }\end{array}$ & $\begin{array}{l}\text { Avg: } 749.5 \\
\text { Avg: } 313.7\end{array}$ & $\begin{aligned} & =2.94 \\
\frac{T_{m=3, p=96}}{T_{m=3, p=288}} & =2.89\end{aligned}$ & 3 & & \\
\hline 768 & $\begin{array}{c}\text { XE6 } \\
\text { XC30 }\end{array}$ & $\begin{array}{l}313.7 \\
141.6\end{array}$ & & & & \\
\hline .. & $\begin{array}{c}\text { XE6 } \\
\text { XC30 }\end{array}$ & $\begin{array}{l}313.0 \\
132.5\end{array}$ & & & & \\
\hline .. & $\begin{array}{c}\text { XE6 } \\
\text { XC30 }\end{array}$ & $\begin{array}{l}310.5 \\
130.2\end{array}$ & & & & \\
\hline .. & $\begin{array}{c}\text { XE6 } \\
\text { XC30 }\end{array}$ & $\begin{array}{l}\text { Avg: } 312.2 \\
\text { Avg: } 134.8\end{array}$ & $\begin{aligned} & =7.06 \\
\frac{T_{m=3, p=96}}{T_{m=3, p=768}} & =6.69\end{aligned}$ & 8 & & \\
\hline
\end{tabular}

- Preparing the different data files for the finite element program requires very tedious bookkeeping when using the traditional MPI paradigm of accumulating large amounts of data before sending them.

- Large nonlinear implicit algorithms for 3-D finite element variably saturated flow calculations can be performed with excellent scalability when increasing the problem size to ever larger numbers of elements.

\section{REFERENCES}

[1] J. Istok, Groundwater modeling by the finite element method, AGU, 1989.

[2] L. A. Richards, Capillary conduction of liquids through porous mediums, J. of Physics, 1 (1931), pp. $318-333$.

3] Y. SAAD, Iterative Methods for Sparse Linear Systems, SIAM, Philadelphia, 2003.

[4] M. Corcoran, J. Peters, J. Dunbar, J. Llopis, F. Tracy, J. Wibowo, J. Simms, C. Kees, S. McKay, J. Fischenich, M. Farthing, M. Glynn, B. Robbins, R. Strange, M. Schultz, J. Clarke, T. Berry, C. Little, and L. Lee, Initial research into the effects of woody vegetation on levees, volume I of IV: project overview, volume II of IV: field data collection, volume III of IV: numerical model simulation, and volume IV of IV: summary of results and conclusions, U.S. Army Engineer Research and Development Center, Vicksburg, MS, 2011.

[5] A. W. WARrick, Soil Water Dynamics, Oxford University Press, 2003.

[6] S. MenL, Use of Picard and Newton iteration for solving nonlinear ground water flow equations, Ground Water, 44 (2006), pp. 583-594.

[7] F. T. Tracy, Testing line search techniques for finite element discretizations for unsaturated flow, Proc. of the 9th Int. Conf. in Computational Science, Baton Rouge, LA, May 25-27, 2009.

[8] C. T. KelleY, Solving nonlinear equations with Newton's method, SIAM, 2003.

[9] H. V. Nguyen, J. C. Cheng, And R. S. Maier, Study of parallel linear solvers for three-dimensional subsurface flow problems, 
TABLE 6.4

Time (sec) for the Cray XE6 and XC30 for $m=4$, nodes $=11967759$, and elements $=23344288$.

\begin{tabular}{|c|c|c|c|c|c|c|}
\hline Processes $(p)$ & Cray & Time $(\mathrm{T})$ & Strong Scaling & Ideal & Weak Scaling & Ideal \\
\hline 128 & $\begin{array}{l}\text { XE6 } \\
\text { XC30 }\end{array}$ & $\begin{array}{c}2229.6 \\
905.1 \\
\end{array}$ & & & & \\
\hline.. & $\begin{array}{c}\text { XE6 } \\
\text { XC30 }\end{array}$ & $\begin{array}{c}2224.3 \\
910.0\end{array}$ & & & & \\
\hline.. & $\begin{array}{c}\text { XE6 } \\
\text { XC30 }\end{array}$ & $\begin{array}{c}2225.2 \\
914.6\end{array}$ & & & & \\
\hline.. & $\begin{array}{c}\text { XE6 } \\
\text { XC30 }\end{array}$ & $\begin{array}{l}\text { Avg: } 2226.4 \\
\text { Avg: } 909.9\end{array}$ & & & $\begin{aligned} & =0.99 \\
\frac{T_{m=1, p=32}}{T_{m=4, p=128}} & =0.99\end{aligned}$ & 1 \\
\hline 256 & $\begin{array}{c}\text { XE6 } \\
\text { XC30 }\end{array}$ & $\begin{array}{c}1102.4 \\
474.6 \\
\end{array}$ & & & & \\
\hline .. & $\begin{array}{c}\text { XE6 } \\
\text { XC30 }\end{array}$ & $\begin{array}{c}1102.6 \\
471.9\end{array}$ & & & & \\
\hline .. & $\begin{array}{c}\text { XE6 } \\
\text { XC30 }\end{array}$ & $\begin{array}{c}1106.0 \\
467.6\end{array}$ & & & & \\
\hline .. & $\begin{array}{c}\text { XE6 } \\
\text { XC30 }\end{array}$ & $\begin{array}{l}\text { Avg: } 1103.7 \\
\text { Avg: } 471.4\end{array}$ & $\begin{aligned} & =2.02 \\
\frac{T_{m=4, p=128}}{T_{m=4, p=256}} & =1.93\end{aligned}$ & 2 & & \\
\hline 384 & $\begin{array}{c}\text { XE6 } \\
\text { XC30 }\end{array}$ & $\begin{array}{l}757.3 \\
332.9\end{array}$ & & & & \\
\hline .. & $\begin{array}{c}\text { XE6 } \\
\text { XC30 } \\
\end{array}$ & $\begin{array}{l}757.2 \\
327.4 \\
\end{array}$ & & & & \\
\hline.. & $\begin{array}{c}\text { XE6 } \\
\text { XC30 }\end{array}$ & $\begin{array}{l}753.7 \\
316.1\end{array}$ & & & & \\
\hline.. & $\begin{array}{c}\mathrm{XE} 6 \\
\mathrm{XC} 30\end{array}$ & $\begin{array}{l}\text { Avg: } 756.1 \\
\text { Avg: } 325.5\end{array}$ & $\begin{aligned} & =2.94 \\
\frac{T_{m=4, p=128}}{T_{m=4, p=384}} & =2.80\end{aligned}$ & 3 & & \\
\hline 1024 & $\begin{array}{c}\text { XE6 } \\
\text { XC30 }\end{array}$ & $\begin{array}{l}312.0 \\
143.8\end{array}$ & & & & \\
\hline.. & $\begin{array}{c}\text { XE6 } \\
\text { XC30 }\end{array}$ & $\begin{array}{l}311.8 \\
137.3\end{array}$ & & & & \\
\hline .. & $\begin{array}{c}\text { XE6 } \\
\text { XC30 }\end{array}$ & $\begin{array}{l}326.2 \\
140.4\end{array}$ & & & & \\
\hline .. & $\begin{array}{c}\mathrm{XE} 6 \\
\mathrm{XC} 30 \\
\end{array}$ & $\begin{array}{l}\text { Avg: } 316.7 \\
\text { Avg: } 140.5\end{array}$ & $\begin{aligned} & =7.03 \\
\frac{T_{m=4, p=128}}{T_{m=4, p=1024}} & =6.48\end{aligned}$ & 8 & & \\
\hline
\end{tabular}

Proc. of the 9th Int. Conf. in Computational Science, Baton Rouge, LA, May 25-27, 2009.

[10] Message Passing Interface Forum, MPI: A Message-Passing Interface Standard, Version 3.0, http://www.mpiforum.org/docs/mpi-3.0/mpi30-report.pdf, 2012.

[11] ERDC DSRC, http://www.erdc.hpc.mil/hardware/index.html, Department of Defense Supercomputing Resource Center, Vicksburg, MS, 2014

[12] AFRL DSRC, http://www.afrl.hpc.mil/index.html, Department of Defense Supercomputing Resource Center, Aberdeen, MD, USA 2014.

[13] G. KARYPIS, ParMETIS - Parallel Graph Partitioning and Fill-reducing Matrix Ordering, http://glaros.dtc.umn.edu/ gkhome/metis/parmetis/overview, 2014.

[14] D. EPPSTEIn, Lecture notes: graph algorithms, http://www.ics.uci.edu/eppstein/161/960201.html, ICS, 161 (1996).

[15] T. H. Cormen, C. E. Leiserson, R. L. Rivest, And C. Stein, Introduction to Algorithms, 3rd ed., Massachusetts Institute of Technology, (2009), pp. 253-280.

[16] Portland Group, Inc., http://www.pgroup.com, 2014.

Edited by: Dana Petcu

Received: Dec 1, 2014

Accepted: Mar 19, 2015 
TABLE 6.5

Time (sec) for the Cray XE6 and XC30 for $m=5$, nodes $=14951223$, and elements $=29180360$.

\begin{tabular}{|c|c|c|c|c|c|c|}
\hline Processes (p) & Cray & Time (T) & Strong Scaling & Ideal & Weak Scaling & Ideal \\
\hline 160 & $\begin{array}{c}\text { XE6 } \\
\text { XC30 }\end{array}$ & $\begin{array}{c}2230.5 \\
910.6\end{array}$ & & & & \\
\hline .. & $\begin{array}{c}\text { XE6 } \\
\text { XC30 }\end{array}$ & $\begin{array}{l}2222.8 \\
911.34\end{array}$ & & & & \\
\hline .. & $\begin{array}{c}\text { XE6 } \\
\text { XC30 }\end{array}$ & $\begin{array}{c}2222.8 \\
911.2\end{array}$ & & & & \\
\hline .. & $\begin{array}{c}\text { XE6 } \\
\text { XC30 }\end{array}$ & $\begin{array}{c}\text { Avg: } 2225.4 \\
\text { Avg: } 911.0\end{array}$ & & & $\begin{aligned} & =0.99 \\
\frac{T_{m=1, p=32}}{T_{m=5, p=160}} & =1.00\end{aligned}$ & 1 \\
\hline 320 & $\begin{array}{c}\text { XE6 } \\
\text { XC30 }\end{array}$ & $\begin{array}{c}1105.6 \\
463.7\end{array}$ & & & & \\
\hline.. & $\begin{array}{c}\text { XE6 } \\
\text { XC30 } \\
\end{array}$ & $\begin{array}{c}1105.4 \\
464.6\end{array}$ & & & & \\
\hline .. & $\begin{array}{c}\text { XE6 } \\
\text { XC30 } \\
\end{array}$ & $\begin{array}{c}1105.3 \\
463.7\end{array}$ & & & & \\
\hline .. & $\begin{array}{c}\text { XE6 } \\
\text { XC30 }\end{array}$ & $\begin{array}{l}\text { Avg: } 1105.4 \\
\text { Avg: } 464.0\end{array}$ & $\begin{aligned} & =2.01 \\
\frac{T_{m=5, p=160}}{T_{m=5, p=320}} & =1.96\end{aligned}$ & 2 & & \\
\hline 480 & $\begin{array}{c}\text { XE6 } \\
\text { XC30 }\end{array}$ & $\begin{array}{l}762.5 \\
314.9\end{array}$ & & & & \\
\hline .. & $\begin{array}{c}\text { XE6 } \\
\text { XC30 }\end{array}$ & $\begin{array}{l}770.9 \\
317.4\end{array}$ & & & & \\
\hline .. & $\begin{array}{c}\text { XE6 } \\
\text { XC30 }\end{array}$ & $\begin{array}{l}761.8 \\
317.4\end{array}$ & & & & \\
\hline .. & $\begin{array}{c}\text { XE6 } \\
\text { XC30 }\end{array}$ & $\begin{array}{l}\text { Avg: } 765.1 \\
\text { Avg: } 316.6\end{array}$ & $\begin{aligned} & =2.94 \\
\frac{T_{m=5, p=160}}{T_{m=5, p=480}} & =2.88\end{aligned}$ & 3 & & \\
\hline 1280 & $\begin{array}{c}\text { XE6 } \\
\text { XC30 } \\
\end{array}$ & $\begin{array}{l}333.2 \\
130.4\end{array}$ & & & & \\
\hline .. & $\begin{array}{c}\text { XE6 } \\
\text { XC30 }\end{array}$ & $\begin{array}{l}335.6 \\
133.5\end{array}$ & & & & \\
\hline.. & $\begin{array}{c}\mathrm{XE} 6 \\
\mathrm{XC} 30 \\
\end{array}$ & $\begin{array}{l}354.5 \\
132.9 \\
\end{array}$ & & & & \\
\hline .. & $\begin{array}{c}\text { XE6 } \\
\text { XC30 }\end{array}$ & $\begin{array}{l}\text { Avg: } 341.1 \\
\text { Avg: } 132.3\end{array}$ & $\begin{aligned} & =6.52 \\
\frac{T_{m=5, p=160}}{T_{m=5, p=1280}} & =6.89\end{aligned}$ & 8 & & \\
\hline
\end{tabular}

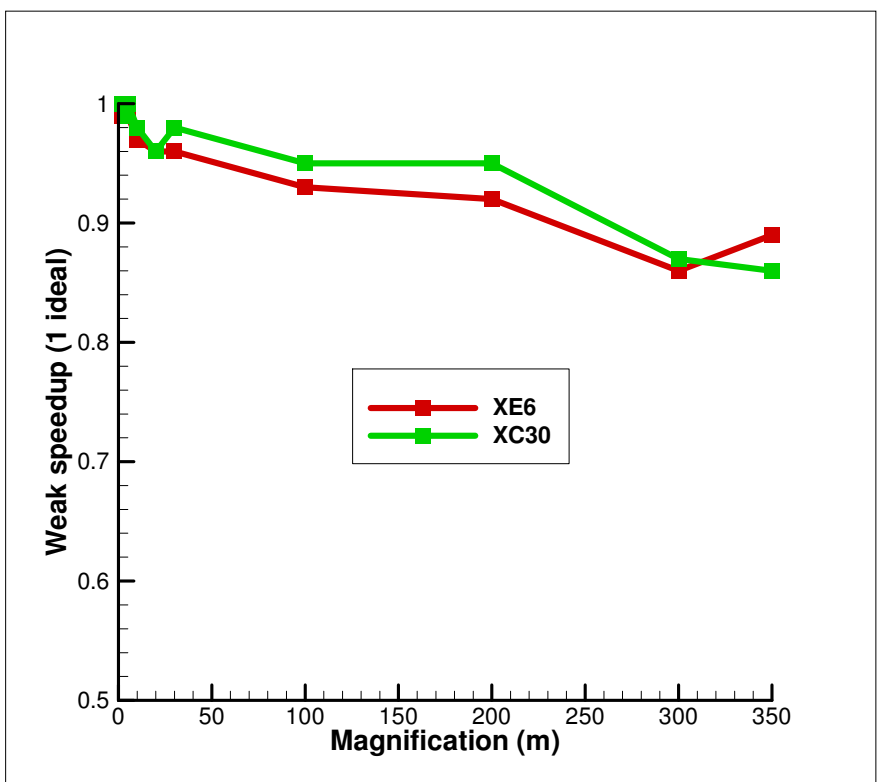

FIG. 6.1. Weak speedup for different $m$ values. 
TABLE 6.6

Time (sec) for the Cray XE6 and XC30 for $m=10$, nodes $=29868543$, and elements $=58360720$.

\begin{tabular}{|c|c|c|c|c|c|c|}
\hline Processes (p) & Cray & Time (T) & Strong Scaling & Ideal & Weak Scaling & Ideal \\
\hline 320 & $\begin{array}{c}\text { XE6 } \\
\text { XC30 }\end{array}$ & $\begin{array}{c}2260.8 \\
916.4\end{array}$ & & & & \\
\hline. & $\begin{array}{c}\text { XE6 } \\
\text { XC30 }\end{array}$ & $\begin{array}{l}2264.3 \\
922.1\end{array}$ & & & & \\
\hline .. & $\begin{array}{c}\text { XE6 } \\
\text { XC30 }\end{array}$ & $\begin{array}{c}2268.6 \\
914.8\end{array}$ & & & & \\
\hline .. & $\begin{array}{c}\text { XE6 } \\
\text { XC30 }\end{array}$ & $\begin{array}{l}\text { Avg: } 2264.6 \\
\text { Avg: } 917.8\end{array}$ & & & $\begin{aligned} & =0.97 \\
\frac{T_{m=1, p=32}}{T_{m=10, p=320}} & =0.98\end{aligned}$ & 1 \\
\hline 640 & $\begin{array}{c}\text { XE6 } \\
\text { XC30 }\end{array}$ & $\begin{array}{c}1138.8 \\
468.9\end{array}$ & & & & \\
\hline .. & $\begin{array}{c}\text { XE6 } \\
\text { XC30 }\end{array}$ & $\begin{array}{c}1143.4 \\
467.2\end{array}$ & & & & \\
\hline .. & $\begin{array}{c}\text { XE6 } \\
\text { XC30 }\end{array}$ & $\begin{array}{l}1137.2 \\
468.7\end{array}$ & & & & \\
\hline .. & $\begin{array}{c}\text { XE6 } \\
\text { XC30 }\end{array}$ & $\begin{array}{l}\text { Avg: } 1139.8 \\
\text { Avg: } 468.3\end{array}$ & $\begin{aligned} & =1.99 \\
\frac{T_{m=10, p=320}}{T_{m=10, p=640}} & =1.96\end{aligned}$ & 2 & & \\
\hline 960 & $\begin{array}{c}\text { XE6 } \\
\text { XC30 }\end{array}$ & $\begin{array}{l}787.0 \\
331.1\end{array}$ & & & & \\
\hline.. & $\begin{array}{c}\text { XE6 } \\
\text { XC30 }\end{array}$ & $\begin{array}{l}774.6 \\
335.9\end{array}$ & & & & \\
\hline .. & $\begin{array}{c}\text { XE6 } \\
\text { XC30 }\end{array}$ & $\begin{array}{l}801.0 \\
347.1\end{array}$ & & & & \\
\hline .. & $\begin{array}{c}\text { XE6 } \\
\text { XC30 }\end{array}$ & $\begin{array}{l}\text { Avg: } 787.5 \\
\text { Avg: } 338.0\end{array}$ & $\begin{aligned} & =2.88 \\
\frac{T_{m=10, p=320}}{T_{m=10, p=960}} & =2.72\end{aligned}$ & 3 & & \\
\hline 2560 & $\begin{array}{c}\text { XE6 } \\
\text { XC30 }\end{array}$ & $\begin{array}{l}447.3 \\
173.4\end{array}$ & & & & \\
\hline .. & $\begin{array}{c}\text { XE6 } \\
\text { XC30 }\end{array}$ & $\begin{array}{l}404.7 \\
156.2\end{array}$ & & & & \\
\hline.. & $\begin{array}{c}\text { XE6 } \\
\text { XC30 }\end{array}$ & $\begin{array}{l}350.3 \\
171.6 \\
\end{array}$ & & & & \\
\hline .. & $\begin{array}{c}\text { XE6 } \\
\text { XC30 }\end{array}$ & $\begin{array}{l}\text { Avg: } 400.8 \\
\text { Avg: } 167.1\end{array}$ & $\begin{aligned} &=5.65 \\
& \frac{T_{m=10, p=320}}{T_{m=10, p=2560}}=5.47\end{aligned}$ & 8 & & \\
\hline
\end{tabular}

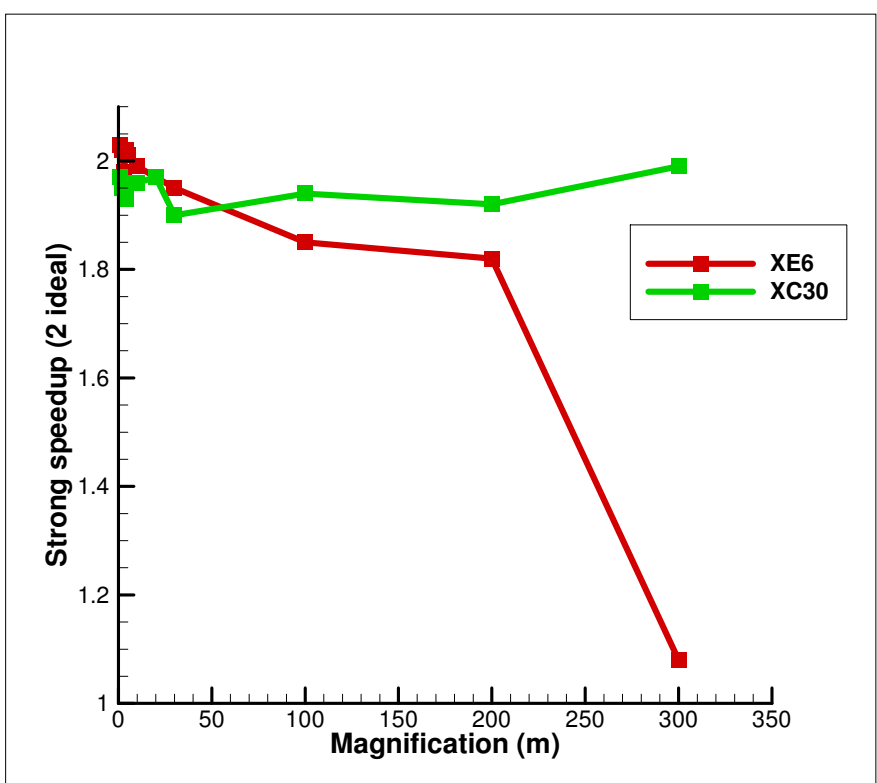

FIG. 6.2. Strong speedup for twice the original number of processes for different $m$ values. 
TABLE 6.7

Time (sec) for the Cray XE6 and XC30 for $m=20$, nodes $=59703183$, and elements $=116721440$.

\begin{tabular}{|c|c|c|c|c|c|c|}
\hline Processes $(\mathrm{p})$ & Cray & Time $(\mathrm{T})$ & Strong Scaling & Ideal & Weak Scaling & Ideal \\
\hline 640 & $\begin{array}{c}\text { XE6 } \\
\text { XC30 }\end{array}$ & $\begin{array}{c}2276.2 \\
918.5\end{array}$ & & & & \\
\hline .. & $\begin{array}{c}\mathrm{XE} 6 \\
\mathrm{XC} 30\end{array}$ & $\begin{array}{c}2287.2 \\
968.4\end{array}$ & & & & \\
\hline .. & $\begin{array}{c}\text { XE6 } \\
\text { XC30 }\end{array}$ & $\begin{array}{c}2277.4 \\
920.0\end{array}$ & & & & \\
\hline .. & $\begin{array}{c}\mathrm{XE} 6 \\
\mathrm{XC} 30\end{array}$ & $\begin{array}{l}\text { Avg: } 2280.3 \\
\text { Avg: } 902.7\end{array}$ & & & $\begin{aligned} & =0.96 \\
\frac{T_{m=1, p=32}}{T_{m=20, p=640}} & =0.96\end{aligned}$ & 1 \\
\hline 1280 & $\begin{array}{c}\mathrm{XE6} \\
\mathrm{XC} 30\end{array}$ & $\begin{array}{l}1152.4 \\
477.4\end{array}$ & & & & \\
\hline .. & $\begin{array}{c}\text { XE6 } \\
\text { XC30 }\end{array}$ & $\begin{array}{c}1171.7 \\
476.5\end{array}$ & & & & \\
\hline .. & $\begin{array}{c}\text { XE6 } \\
\text { XC30 }\end{array}$ & $\begin{array}{c}153.0 \\
472.6\end{array}$ & & & & \\
\hline .. & $\begin{array}{c}\mathrm{XE} 6 \\
\mathrm{XC} 30\end{array}$ & $\begin{array}{l}\text { Avg: } 1159.0 \\
\text { Avg: } 475.5\end{array}$ & $\begin{aligned} & =1.97 \\
\frac{T_{m=20, p=640}}{T_{m=20, p=1280}} & =1.97\end{aligned}$ & 2 & & \\
\hline 1920 & $\begin{array}{c}\text { XE6 } \\
\text { XC30 }\end{array}$ & $\begin{array}{l}805.5 \\
323.2\end{array}$ & & & & \\
\hline .. & $\begin{array}{c}\text { XE6 } \\
\text { XC30 }\end{array}$ & $\begin{array}{l}812.3 \\
329.3\end{array}$ & & & & \\
\hline .. & $\begin{array}{c}\text { XE6 } \\
\text { XC30 }\end{array}$ & $\begin{array}{l}805.8 \\
324.1\end{array}$ & & & & \\
\hline .. & $\begin{array}{c}\mathrm{XE6} \\
\mathrm{XC} 30\end{array}$ & $\begin{array}{l}\text { Avg: } 807.9 \\
\text { Avg: } 325.5\end{array}$ & $\begin{aligned} & =2.82 \\
\frac{T_{m=20, p=640}}{T_{m=20, p=1920}} & =2.87\end{aligned}$ & 3 & & \\
\hline 5120 & $\begin{array}{c}\text { XE6 } \\
\text { XC30 }\end{array}$ & $\begin{array}{l}410.8 \\
141.1\end{array}$ & & & & \\
\hline .. & $\begin{array}{c}\text { XE6 } \\
\text { XC30 }\end{array}$ & $\begin{array}{l}402.2 \\
140.1\end{array}$ & & & & \\
\hline .. & $\begin{array}{c}\text { XE6 } \\
\text { XC30 }\end{array}$ & $\begin{array}{l}408.7 \\
140.9\end{array}$ & & & & \\
\hline .. & $\begin{array}{c}\mathrm{XE6} \\
\mathrm{XC} 30\end{array}$ & $\begin{array}{l}\text { Avg: } 407.2 \\
\text { Avg: } 140.7\end{array}$ & $\begin{aligned} & =5.59 \\
\frac{T_{m=20, p=640}}{T_{m=20, p=5120}} & =6.65\end{aligned}$ & 8 & & \\
\hline
\end{tabular}

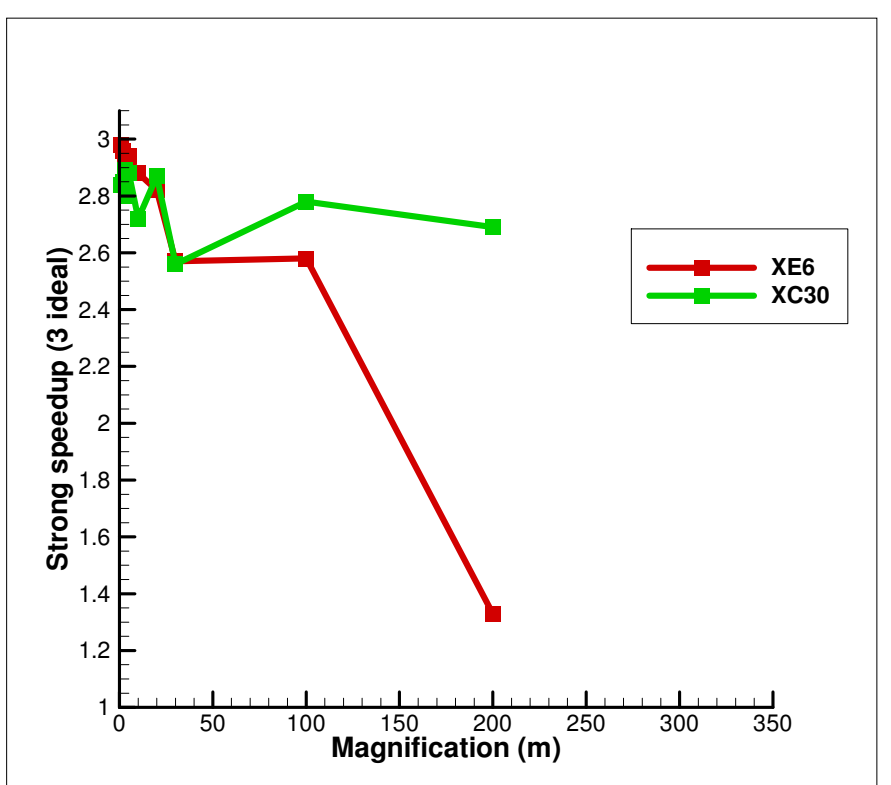

FIG. 6.3. Strong speedup for three times the original number of processes for different $m$ values. 
TABLE 6.8

Time (sec) for the Cray XE6 and XC30 for $m=30$, nodes $=89537823$, and elements $=175082160$.

\begin{tabular}{|c|c|c|c|c|c|c|}
\hline Processes (p) & Cray & Time (T) & Strong Scaling & Ideal & Weak Scaling & Ideal \\
\hline 960 & $\begin{array}{c}\text { XE6 } \\
\text { XC30 }\end{array}$ & $\begin{array}{c}2276.5 \\
924.1\end{array}$ & & & & \\
\hline .. & $\begin{array}{c}\text { XE6 } \\
\text { XC30 }\end{array}$ & $\begin{array}{l}2278.5 \\
922.7\end{array}$ & & & & \\
\hline .. & $\begin{array}{c}\text { XE6 } \\
\text { XC30 }\end{array}$ & $\begin{array}{c}2277.9 \\
923.7\end{array}$ & & & & \\
\hline .. & $\begin{array}{c}\text { XE6 } \\
\text { XC30 }\end{array}$ & $\begin{array}{l}\text { Avg: } 2277.6 \\
\text { Avg: } 923.5\end{array}$ & & & $\begin{aligned} &=0.96 \\
& \frac{T_{m=1, p=32}}{T_{m=30, p=960}}=0.98\end{aligned}$ & 1 \\
\hline 1920 & $\begin{array}{c}\text { XE6 } \\
\text { XC30 }\end{array}$ & $\begin{array}{c}1172.5 \\
473.0\end{array}$ & & & & \\
\hline.. & $\begin{array}{c}\text { XE6 } \\
\text { XC30 } \\
\end{array}$ & $\begin{array}{c}1165.8 \\
473.4\end{array}$ & & & & \\
\hline .. & $\begin{array}{c}\text { XE6 } \\
\text { XC30 } \\
\end{array}$ & $\begin{array}{l}1159.7 \\
514.6\end{array}$ & & & & \\
\hline .. & $\begin{array}{c}\text { XE6 } \\
\text { XC30 }\end{array}$ & $\begin{array}{l}\text { Avg: } 1166.0 \\
\text { Avg: } 487.0\end{array}$ & $\begin{aligned} & =1.95 \\
\frac{T_{m=30, p=960}}{T_{m=30, p=1920}} & =1.90\end{aligned}$ & 2 & & \\
\hline 2880 & $\begin{array}{c}\text { XE6 } \\
\text { XC30 }\end{array}$ & $\begin{array}{l}889.7 \\
348.8\end{array}$ & & & & \\
\hline .. & $\begin{array}{c}\text { XE6 } \\
\text { XC30 }\end{array}$ & $\begin{array}{l}895.0 \\
364.8\end{array}$ & & & & \\
\hline .. & $\begin{array}{c}\text { XE6 } \\
\text { XC30 }\end{array}$ & $\begin{array}{l}872.4 \\
370.0\end{array}$ & & & & \\
\hline$\cdot$. & $\begin{array}{c}\text { XE6 } \\
\text { XC30 }\end{array}$ & $\begin{array}{l}\text { Avg: } 885.7 \\
\text { Avg: } 361.2\end{array}$ & $\begin{aligned} & =2.57 \\
\frac{T_{m=30, p=960}}{T_{m=30, p=2880}} & =2.56\end{aligned}$ & 3 & & \\
\hline 7680 & $\begin{array}{c}\text { XE6 } \\
\text { XC30 } \\
\end{array}$ & $\begin{array}{l}398.7 \\
139.9\end{array}$ & & & & \\
\hline .. & $\begin{array}{c}\text { XE6 } \\
\text { XC30 }\end{array}$ & $\begin{array}{l}429.1 \\
139.4\end{array}$ & & & & \\
\hline.. & $\begin{array}{c}\mathrm{XE} 6 \\
\mathrm{XC} 30 \\
\end{array}$ & $\begin{array}{l}447.1 \\
138.2 \\
\end{array}$ & & & & \\
\hline .. & $\begin{array}{c}\text { XE6 } \\
\text { XC30 }\end{array}$ & $\begin{array}{l}\text { Avg: } 425.0 \\
\text { Avg: } 139.2\end{array}$ & $\begin{aligned} & =5.36 \\
\frac{T_{m=30, p=960}}{T_{m=30, p=7680}} & =6.72\end{aligned}$ & 8 & & \\
\hline
\end{tabular}

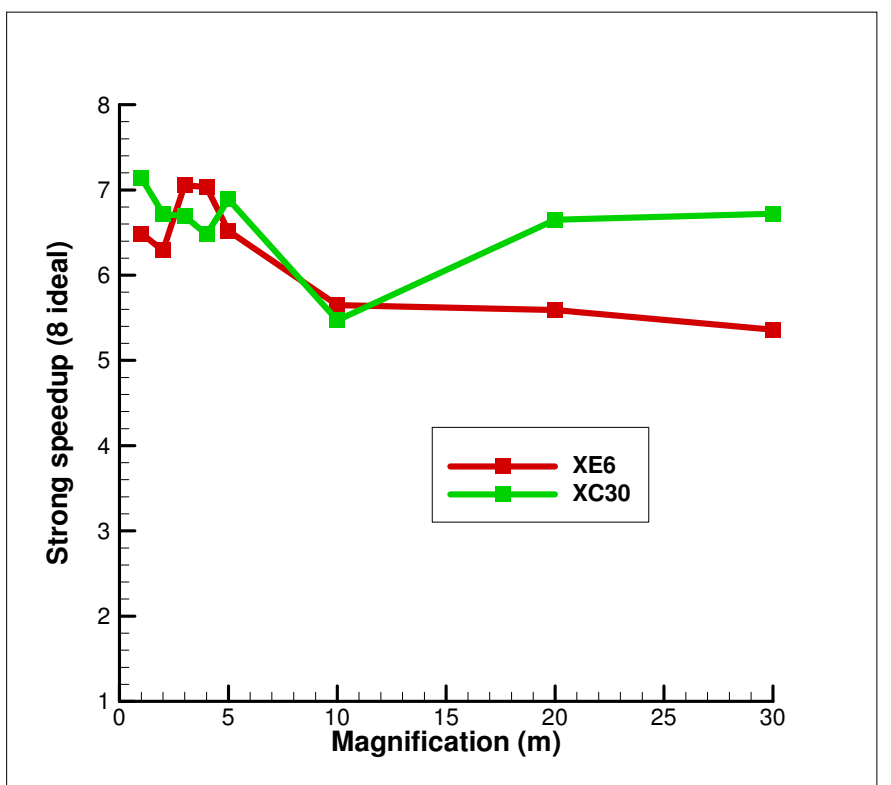

FIG. 6.4. Strong speedup for eight times the original number of processes for different $m$ values. 
TABLE 6.9

Time (sec) for the Cray XE6 and XC30 for $m=100$, nodes $=298380303$, and elements $=583607200$.

\begin{tabular}{|c|c|c|c|c|c|c|}
\hline Processes $(p)$ & Cray & Time $(\mathrm{T})$ & Strong Scaling & Ideal & Weak Scaling & Ideal \\
\hline 3200 & $\begin{array}{c}\text { XE6 } \\
\text { XC30 }\end{array}$ & $\begin{array}{c}2369.4 \\
969.6\end{array}$ & & & & \\
\hline .. & $\begin{array}{c}\mathrm{XE} 6 \\
\mathrm{XC} 30\end{array}$ & $\begin{array}{l}2358.4 \\
934.2\end{array}$ & & & & \\
\hline .. & $\begin{array}{c}\mathrm{XE6} \\
\text { XC30 }\end{array}$ & $\begin{array}{c}2359.9 \\
961.3\end{array}$ & & & & \\
\hline .. & $\begin{array}{c}\mathrm{XE} 6 \\
\mathrm{XC} 30\end{array}$ & $\begin{array}{l}\text { Avg: } 2362.6 \\
\text { Avg: } 955.0\end{array}$ & & & $\begin{aligned} & =0.93 \\
\frac{T_{m=1, p=32}}{T_{m=100, p=3200}} & =0.95\end{aligned}$ & 1 \\
\hline 6400 & $\begin{array}{c}\text { XE6 } \\
\text { XC30 }\end{array}$ & $\begin{array}{c}1228.4 \\
479.2\end{array}$ & & & & \\
\hline .. & $\begin{array}{c}\mathrm{XE} 6 \\
\mathrm{XC} 30\end{array}$ & $\begin{array}{c}1357.0 \\
499.5\end{array}$ & & & & \\
\hline .. & $\begin{array}{c}\text { XE6 } \\
\text { XC30 }\end{array}$ & $\begin{array}{c}1250.3 \\
498.7\end{array}$ & & & & \\
\hline .. & $\begin{array}{c}\mathrm{XE} 6 \\
\mathrm{XC} 30\end{array}$ & $\begin{array}{l}\text { Avg: } 1278.6 \\
\text { Avg: } 492.5\end{array}$ & $\begin{aligned} & =1.85 \\
\frac{T_{m=100, p=3200}}{T_{m=100, p=6400}} & =1.94\end{aligned}$ & 2 & & \\
\hline 9600 & $\begin{array}{c}\text { XE6 } \\
\text { XC30 }\end{array}$ & $\begin{array}{l}899.8 \\
339.2\end{array}$ & & & & \\
\hline .. & $\begin{array}{c}\text { XE6 } \\
\text { XC30 }\end{array}$ & $\begin{array}{l}897.4 \\
352.4\end{array}$ & & & & \\
\hline .. & $\begin{array}{c}\text { XE6 } \\
\text { XC30 }\end{array}$ & $\begin{array}{l}952.1 \\
354.1\end{array}$ & & & & \\
\hline .. & $\begin{array}{c}\mathrm{XE} 6 \\
\mathrm{XC} 30\end{array}$ & $\begin{array}{l}\text { Avg: } 916.4 \\
\text { Avg: } 348.6\end{array}$ & $\begin{aligned} & =2.58 \\
\frac{T_{m=100, p=3200}}{T_{m=100, p=9600}} & =2.78\end{aligned}$ & 3 & & \\
\hline
\end{tabular}

TABLE 6.10

Time (sec) for the Cray XE6 and XC30 for $m=200$, nodes $=596726703$, and elements $=1167214400$.

\begin{tabular}{|c|c|c|c|c|c|c|}
\hline Processes $(\mathrm{p})$ & Cray & Time $(\mathrm{T})$ & Strong Scaling & Ideal & Weak Scaling & Ideal \\
\hline 6400 & $\begin{array}{c}\text { XE6 } \\
\text { XC30 }\end{array}$ & $\begin{array}{c}2394.4 \\
947.3\end{array}$ & & & & \\
\hline .. & $\begin{array}{c}\text { XE6 } \\
\text { XC30 }\end{array}$ & $\begin{array}{c}2391.1 \\
943.6\end{array}$ & & & & \\
\hline .. & $\begin{array}{c}\text { XE6 } \\
\text { XC30 }\end{array}$ & $\begin{array}{c}2392.4 \\
945.3\end{array}$ & & & & \\
\hline .. & $\begin{array}{c}\text { XE6 } \\
\text { XC30 }\end{array}$ & $\begin{array}{l}\text { Avg: } 2392.6 \\
\text { Avg: } 945.4\end{array}$ & & & $\begin{aligned} & =0.92 \\
\frac{T_{m=1, p=32}}{T_{m=200, p=6400}} & =0.95\end{aligned}$ & 1 \\
\hline 12800 & $\begin{array}{c}\mathrm{XE} 6 \\
\mathrm{XC} 30\end{array}$ & $\begin{array}{l}1300.0 \\
494.8\end{array}$ & & & & \\
\hline .. & $\begin{array}{c}\mathrm{XE} 6 \\
\mathrm{XC} 30\end{array}$ & $\begin{array}{l}1292.8 \\
493.0\end{array}$ & & & & \\
\hline .. & $\begin{array}{c}\text { XE6 } \\
\text { XC30 }\end{array}$ & $\begin{array}{c}1340.4 \\
488.3\end{array}$ & & & & \\
\hline * & $\begin{array}{c}\text { XE6 } \\
\text { XC30 }\end{array}$ & $\begin{array}{l}\text { Avg: } 1311.1 \\
\text { Avg: } 492.0\end{array}$ & $\begin{aligned} & =1.82 \\
\frac{T_{m=200, p=6400}}{T_{m=200, p=12800}} & =1.92\end{aligned}$ & 2 & & \\
\hline 19200 & $\begin{array}{c}\text { XE6 } \\
\text { XC30 }\end{array}$ & $\begin{array}{c}1783.5 \\
351.2\end{array}$ & & & & \\
\hline .. & $\begin{array}{c}\text { XE6 } \\
\text { XC30 }\end{array}$ & $\begin{array}{c}1782.0 \\
350.3\end{array}$ & & & & \\
\hline .. & $\begin{array}{c}\text { XE6 } \\
\text { XC30 }\end{array}$ & $\begin{array}{c}1839.1 \\
352.6\end{array}$ & & & & \\
\hline .. & $\begin{array}{c}\text { XE6 } \\
\text { XC30 }\end{array}$ & $\begin{array}{l}\text { Avg: } 1801.5 \\
\text { Avg: } 351.4\end{array}$ & $\begin{aligned} & =1.33 \\
\frac{T_{m=200, p=6400}}{T_{m=200, p=19200}} & =2.69\end{aligned}$ & 3 & & \\
\hline
\end{tabular}


TABLE 6.11

Time (sec) for the Cray XE6 and XC30 for $m=300$, nodes $=895073103$, and elements $=1750821600$.

\begin{tabular}{|c|c|c|c|c|c|c|}
\hline Processes (p) & Cray & Time $(\mathrm{T})$ & Strong Scaling & Ideal & Weak Scaling & Ideal \\
\hline 9600 & $\begin{array}{c}\text { XE6 } \\
\text { XC30 }\end{array}$ & $\begin{array}{l}2671.7 \\
1039.2\end{array}$ & & & & \\
\hline .. & $\begin{array}{c}\text { XE6 } \\
\text { XC30 }\end{array}$ & $\begin{array}{l}2442.3 \\
1041.0\end{array}$ & & & & \\
\hline .. & $\begin{array}{c}\text { XE6 } \\
\text { XC30 }\end{array}$ & $\begin{array}{l}2566.9 \\
1034.9\end{array}$ & & & & \\
\hline .. & $\begin{array}{c}\mathrm{XE6} 6 \\
\mathrm{XC} 30 \\
\end{array}$ & $\begin{array}{l}\text { Avg: } 2560.3 \\
\text { Avg: } 1038.4\end{array}$ & & & $\begin{aligned} & =0.86 \\
\frac{T_{m=1, p=32}}{T_{m=300, p=9600}} & =0.87\end{aligned}$ & 1 \\
\hline 19200 & $\begin{array}{c}\text { XE6 } \\
\text { XC30 }\end{array}$ & $\begin{array}{c}2351.4 \\
512.3\end{array}$ & & & & \\
\hline .. & $\begin{array}{c}\text { XE6 } \\
\text { XC30 }\end{array}$ & $\begin{array}{c}2390.8 \\
517.1\end{array}$ & & & & \\
\hline .. & $\begin{array}{c}\text { XE6 } \\
\text { XC30 }\end{array}$ & $\begin{array}{c}2392.9 \\
527.2\end{array}$ & & & & \\
\hline .. & $\begin{array}{r}\mathrm{XE} 6 \\
\mathrm{XC} 30\end{array}$ & $\begin{array}{l}\text { Avg: } 2378.4 \\
\text { Avg: } 522.2\end{array}$ & $\begin{aligned} & =1.08 \\
\frac{T_{m=300, p=9600}}{T_{m=300, p=19200}} & =1.99\end{aligned}$ & 2 & & \\
\hline
\end{tabular}

TABLE 6.12

Time (sec) for the Cray XE6 and XC30 for $m=350$, nodes $=1044246303$, and elements $=2042625200$.

\begin{tabular}{|c|c|c|c|c|c|c|}
\hline Processes (p) & Cray & Time (T) & Strong Scaling & Ideal & Weak Scaling & Ideal \\
\hline \multirow{2}{*}{11200} & XE6 & 2464.6 & & & & \\
\hline & XC30 & 1041.9 & & & & \\
.. & XE6 & 2510.2 & & & & \\
.. & XC30 & 1048.6 & & & & \\
\hline. & XE6 & 2424.8 & & & & \\
\hline & XE30 & 1043.1 & & & & \\
\hline
\end{tabular}

TABLE 6.13

Ratio of running times for the XE6 and XC30 for values of $m$.

\begin{tabular}{|c|c|c|c|c|c|c|}
\hline$m$ & 1 & 2 & 3 & 4 & 5 & 10 \\
\hline Ratio & 2.45 & 2.46 & 2.39 & 2.34 & 2.45 & 2.41 \\
\hline \hline$m$ & 20 & 30 & 100 & 200 & 300 & 350 \\
\hline Ratio & 2.58 & 2.59 & 2.57 & 3.44 & 3.51 & 2.36 \\
\hline
\end{tabular}

TABLE 7.1

Consistency check comparing values of pressure head from the original mesh and the mesh for $m=350$ for the first few nodes and last few nodes of each mesh.

\begin{tabular}{|c|c|c|c|}
\hline Node & $m=1$ & Node & $m=350$ \\
\hline 1 & 129.00000 & 1 & 129.00000 \\
\hline 2 & 128.99678 & 2 & 128.99678 \\
\hline 3 & 128.99345 & 3 & 128.99345 \\
\hline 4 & 119.00000 & 4 & 119.00000 \\
\hline 5 & 118.99735 & 5 & 118.99735 \\
\hline 6 & 124.23808 & 6 & 124.23808 \\
\hline 7 & 118.99464 & 7 & 118.99464 \\
\hline 8 & 123.54520 & 8 & 123.54520 \\
\hline 9 & 128.98993 & 9 & 128.98993 \\
\hline 10 & 110.50000 & 10 & 110.50000 \\
\hline 6000826 & 0.00000 & 1044246298 & 0.00000 \\
\hline 6000827 & 0.041718481 & 1044246299 & 0.041718484 \\
\hline 6000828 & 3.0365778 & 1044246300 & 3.0365778 \\
\hline 6000829 & 0.036494874 & 1044246301 & 0.036494874 \\
\hline 6000830 & 0.00000 & 1044246302 & 0.00000 \\
\hline 6000831 & 0.00000 & 1044246303 & 0.00000 \\
\hline
\end{tabular}

